\title{
The Charles Waddell Chesnutt Collection at Fayetteville State University
}

7 he history of Fayetteville State University and its Charles W. Chesnutt Library are intimately connected with one of the most important writers from North Carolina. Charles Waddell Chesnutt, 18581933, was a celebrated short story writer and novelist who tackled issues of race and class in ways that still resonate today.

Fayetteville State University was founded by a group of seven African American men in 1867 as the Howard School. One of these men was Andrew Jackson Chesnutt, the father of Charles W. Chesnutt. Andrew Chesnutt was from Cleveland, Ohio, and had settled in Fayetteville after the end of the Civil War to raise his children near his parents. Andrew Chesnutt opened a grocery store and later a dry goods transportation business. ${ }^{1,2}$ Chesnutt's son, Charles, and daughters Lillian, Anne, and Sara attended the school he helped found, a school which quickly grew in importance to Fayetteville and the state.

The Howard School was renamed the State Colored Normal School in 1877, and subsequently became Fayetteville State Teachers College with the ability to grant Bachelor's degrees in education in 1933. It was renamed Fayetteville State University, and then in 1972 made a part of the University of North Carolina system. ${ }^{3}$ The original Charles W. Chesnutt Library opened its doors in 1937 in a building which now houses university telecommunications. The second Chesnutt Library, built in 1968, is now the Helen Chick Building. ${ }^{4}$ The current building was constructed in 1987 and named after Charles Waddell Chesnutt. The 30-strong staff welcome students, faculty, and researchers to their 4-story, 70-000 square-foot facility.

Charles Waddell Chesnutt was a student and teacher at the Howard School in Fayetteville which was later renamed the State Colored Normal School. After a stint teaching in Charlotte, he returned to serve as assistant principal in 1877, and then he became principal in 1880. Chesnutt spent a brief time in New York and then moved permanently back to Ohio. There, he passed the bar and worked as a lawyer and later a stenographer. Although his first short story "Uncle Peter's House" was published in the Cleveland News and Herald in 1885, Chesnutt's literary career took off in 1887 when his short story "The Goophered Grapevine" became the first African-American publication in the Atlantic Monthly. 5 This story was collected in his 1899 book, The Conjure Woman. The same year he published a second book of short stories, The Wife of His Youth and Other Stories of the Color Line. These and other short stories Chesnutt wrote address issues of race and class, passing and miscegenation-themes of expression that are also in his novels.

In 1900, Chesnutt's first novel The House Behind the Cedars was published by Houghton Mifflin. A novel that tells the story of an African American woman who moves to the same city as her brother, both passing for white until the sister's fiancé discovers her secret. Chesnutt's second novel was The Marrow of Tradition, published in 1901. The Marrow of Tradition is based on the Wilmington race riots of 1898. It is significant that Chesnutt's novels were published at the same time that Jim Crow laws were exerting tremendous political clout in North Carolina and other Southern states. Chesnutt's third and final novel was The Colonel's Dream, published in 1905. After that time, he stopped writing commercially, but involved himself more in civic affairs.

Chesnutt participated in the Niagara Movement meeting at Oberlin College in 1908, delivering the welcoming address on August $28 .{ }^{6} \mathrm{He}$ also participated in the founding of the NAACP in 1909, serving on the General Committee. In 1928, he was awarded the NAACP's Springarn Medal for "for his pioneer work as a literary artist, depicting the life and struggle of Americans of Negro descent".

Among the treasures in Chesnutt Library is the Charles Waddell Chesnutt Collection, which contains materials from 1821 to 1967 . The 


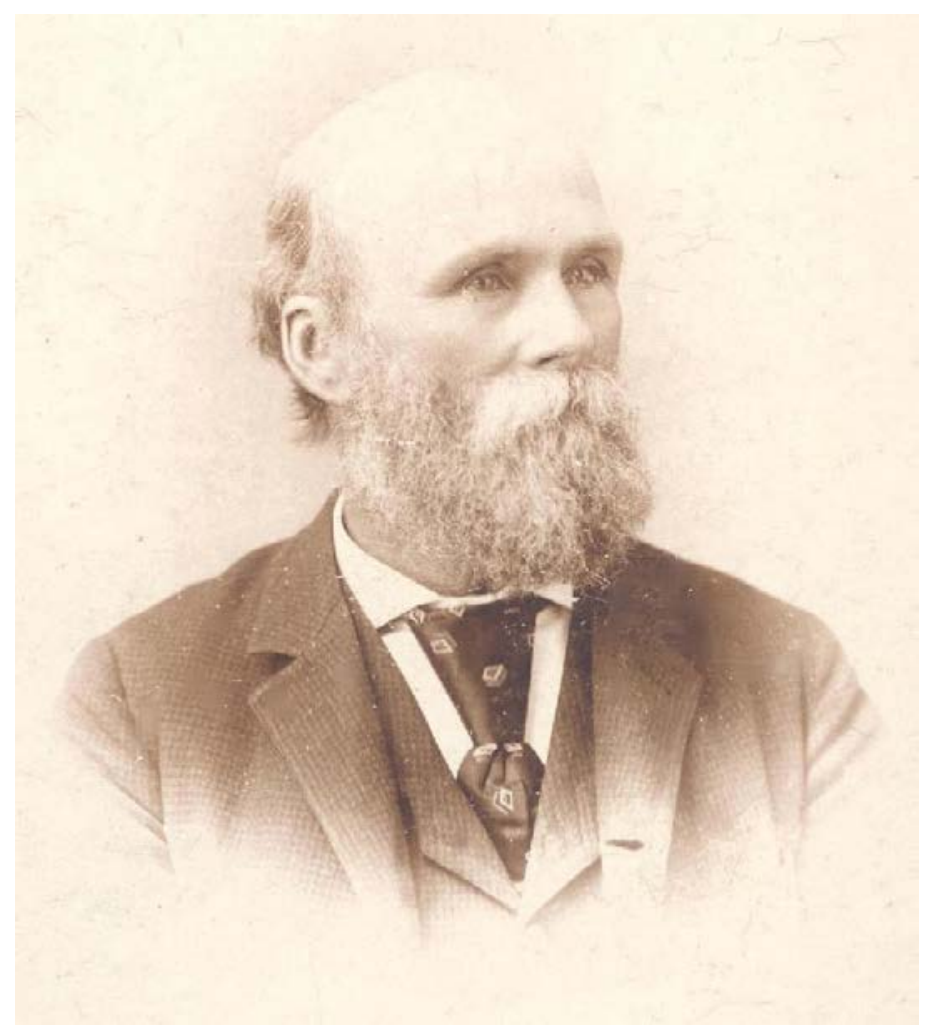

Image 1: Andrew J. Chesnutt

Chesnutt Collection includes correspondence of Charles Chesnutt, letters and records of his sisters Anne C. Waddell and Sara Chesnutt, pictures of family and friends, newspaper and magazine clippings, and postcards. Finding aids for all three are available online, along with selected digitized materials. Correspondents for Chesnutt includes famed educator and author Booker T. Washington, wellregarded editor and fellow North Carolinian, Walter Hines Page, and William Dean Howells, editor of the Atlantic Monthly, who was also called the "Dean of American Letters." Charles's sisters, Sara and Anne, also attended Fayetteville State and were active educators in Fayetteville. In fact, Anne Chesnutt Waddell served as a teacher, principal and superintendent, and had a high school (now a middle school) named after her. ${ }^{8}$

The Chesnutt Collection has several items digitized through an LSTA award in 2003. Mr. Bobby Wynn, Director of the library, describes the reason the Chesnutt Collection was selected for this grant application: "The Charles Chesnutt Family collection provides a historical look into an effort by one family to provide for the education of their children and other African American children" during the Reconstruction period between the end of the Civil War and the end of the Nineteenth Century. ${ }^{\text {? }}$

According to Ms. Nicholle Young, University Library Technician for Archives, researchers have come from UNC Chapel Hill, Fisk University, and Bowdoin College to consult the Chesnutt Collection. Some of her favorite items in the collection are the photographs of the Chesnutts' travels around Fayetteville, to Cleveland, and abroad. Moreover, she enjoys sharing Charles Chesnutt's handwritten letters, helping patrons create a personal connection with the author. In common with Chesnutt, she loves the city and wants to see it grow and thrive. Among the most requested items from the Chesnutt Collection are correspondence of Anne and Sara Chesnutt, especially for researchers of the history of education in Fayetteville.

The Chesnutt Collection fits well with the library's mission to provide students primary materials related to the university's history, its transition through the years and its place within state and national history, especially during the Great Depression and the World Wars, two a time of significant change at Fayetteville State. Ms. Young and her colleagues are beginning to prepare for the University's sesquicentennial, so she is looking at materials from the presidents' papers. For the Special Collections as a whole, additional heavily-requested items include presidential speeches, particularly from Dr. Rudolph Jones and Dr. James Ward Seabrook, who presided over critical transition points in the history of the university. She believes that Charles Chesnutt, Dr. Jones and Dr. Seabrook, among others, have held similar visions for the University to provide education and service to the city and state.

The Chesnutt Collection provides rich primary source materials related to education in Fayetteville and issues of race and class. Interested readers can find Chesnutt's works at Documenting the American South, and in the Chesnutt Digital Archive. ${ }^{10}$ There are also Charles Chesnutt Collections at Western Reserve Historical University in Cleveland, Ohio, and Fisk University in Nashville, Tennessee. But Ms. Young, Mr. Wynn, and the other librarians at Chesnutt Library invite everyone to visit Special Collections at Charles W. Chesnutt Library at Fayetteville State University.

Thanks to Nicholle Young, University Library Technician for Archives, Charles W. Chesnutt Library, Fayetteville State University 


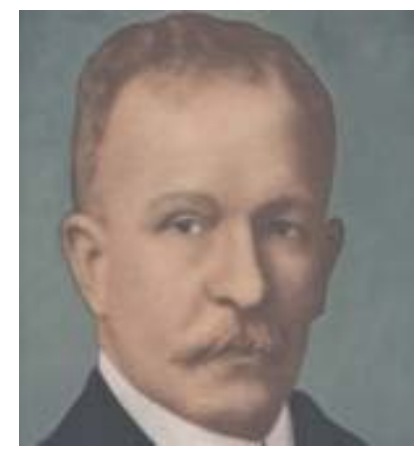

Image 2: Charles W. Chesnutt, 2nd Principal of Howard School (later Fayetteville State University)

\section{References}

1 "History of Fayetteville State University," Charles W. Chesnutt Library Archives and Special Collections, Fayetteville State University, http://library.uncfsu.edu/archives/fsu-history.

2 Amber Covington, "FSU History: Founding Fathers," Charles W. Chesnutt Library Archives and Special Collection, Fayetteville State University, September 25, 2014. http://chesnuttlibrary.tumblr.com/post/98404702706/fsu-history-founding-fathers-in-a-short-letter.

3 "History of Fayetteville State University," ibid.

${ }^{3}$ Joan Milligan et al, "Chronological History of Fayetteville State University Buildings and Structures 1867 - Present Date," Charles W. Chesnutt Library Archives and Special Collections, Fayetteville State University, http://library. uncfsu.edu/archives/history-of-fsu-campus-buildings.

4 "Digitization Project Background Information," Charles W. Chesnutt Library Archives and Special Collections, Fayetteville State University, http://library.uncfsu.edu/archives/digitized-collections/digitization-project-backgroundinformation.

5 "Biography," The Charles Chesnutt Digital Archive, http://www.chesnuttarchive.org/classroom/biography.html.

6 "The Niagara Group," Electronic Oberlin Group, http://www.oberlin.edu/external/EOG/Niagara\%20Movement/ niagaramain.htm.

7 Samuel W. Black, "Researching the African-American Experience at the Western Reserve Historical Society," Crooked River: An Electronic Journal of Social and Urban History 3 (December 2000). Available at http://academic.csuohio.

edu/clevelandhistory/Issue3/articles/RESEARCHING_THE_AFRICAN_AMERICAN_EXPERIENCE_AT_THE_ WESTERN_R.html.

${ }^{8}$ Darwin Hedrick, "Brief History of Anne Chesnutt School," Anne Chesnutt Year-Round Middle School, March 2, 2015, http://acms.ccs.k12.nc.us/category/school-history/.

9 "Digitization Project Background Information," ibid.

${ }^{10}$ Browner, Stephanie, "The Charles Chesnutt Digital Archive," http://www.chesnuttarchive.org/. "Charles Waddell Chesnutt, 1858-1932," Documenting the American South. University of North Carolina at Chapel Hill, http:// docsouth.unc.edu/southlit/chesnuttcolonel/bio.html.

See also Alice Thrasher, "New Generation Learns to Appreciate Chestnutt's [sic] Work," Fayetteville Observer February 8, 1998, http://www.fayobserver.com/living/new-generation-learns-to-appreciate-chestnutt-s-work/article_9049eb083aae-5193-967c-54916c6f10af.html. 